All106 97886

NBSIR 81-1654

\title{
LOW TEMPERATURE MECHANICAL PROPERTIES OF A POLYURETHANE FOAM
}

J.M. Arvidson

L.L. Sparks

National Bureau of Standards

U.S. Department of Commerce

Boulder, Colorado 80303

Prepared for:

Gas Research Institute

8600 West Bryn Mawr Avenue

Chicago, Illinois 60631

November 1981 



\section{NBSIR 81-1654}

\section{LOW TEMPERATURE MECHANICAL PROPERTIES OF A POLYURETHANE FOAM}

J.M. Arvidson $\dagger$

L.L. Sparks $+\dagger$

† Fracture and Deformation Division

National Measurement Laboratory

$\dagger \dagger$ Thermophysical Properties Division

National Engineering Laboratory

National Bureau of Standards

U.S. Department of Commerce

Boulder, Colorado 80303

November 1981

Prepared for:

Gas Research Institute

8600 West Bryn Mawr Avenue

Chicago, Illinois 60631

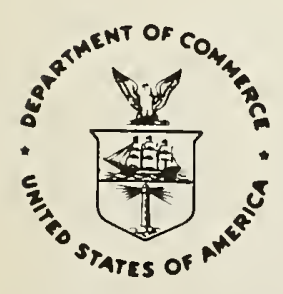

U.S. DEPARTMENT OF COMMERCE, Malcolm Baldrige, Secretary 



\section{Low Temperature Ilechanical Properties of a Polyurethane Foam†}

\section{J. M. Arvidson and L. L. Sparks}

Polyurethane foam, having a density of $32 \mathrm{~kg} / \mathrm{m}^{3}$, was tested at 295, 111,76 , and $45 \mathrm{~K}$ in helium gas. The material properties reported are Young's modulus, proportional 1imit, yield strength (at $0.2 \%$ offset), tensile, shear, and compressive strengths, and elongation (elastic and plastic). To perform these tests, a unique apparatus was developed. This apparatus permits tension, compression, and shear testing of materials at any temperature ranging from 295 to $4 \mathrm{~K}$. Strain is measured with a concentric, overlapping-cylinder capacitance extensometer that is highly sensitive and linear in output.

Key words: Compressive strength; elongation; foam; insulation; low temperature; mechanical properties; proportional limit; shear strength; tensile strength; yield strength; Young's modulus.

\section{INTRODUCTION}

Safe, economical storage and transportation of liquefied gases depend to a large extent on the materials used in capital equipment, i.e., storage facilities, transfer terminals, liquefiers, pipelines, and ships. Thermal insulations constitute a critical link in the materials for use in LNG and LPG oriented energy efforts because of the cryogenic nature of the liquids. Accurate data, predictive capability, and standardized methods and materials will improve the selection and development of insulating materials for these applications. The mechanical properties reported are part of a broader effort to understand and be able to predict the thermal and mechanical behavior of expanded plastics (foams) in cryogenic environments.

The tensile, compressive, and shear properties of polyurethane foam, having a density of $32 \mathrm{~kg} / \mathrm{m}^{3}$, were determined using a test fixture developed specifically for this program. This fixture provides the capability of determining the above material properties at any temperature from ambient $(295 \mathrm{~K})$ to near $4 \mathrm{~K}$, in a cold helium-gas atmosphere. Tests can also be done in liquids, such as helium ( $4 \mathrm{~K})$, nitrogen (76 K), and dry ice and alcohol ( $195 \mathrm{~K})$. The fixture can also be used for tests on materials at the above temperatures while under static pressures ranging from atmospheric to approximately $0.3 \mathrm{MPa}$ ( $30 \mathrm{psig}$ ).

A strain extensometer was developed for use with soft viscoelastic materials. The technique [1] utilizes concentric overlapping cylinders and the change in electrical capacitance to detect specimen strain. This type of extensometer does not attach directly to the specimen so that the effect of instrumentation on the experimental results is minimized. The extensometer works well in cryogenic environments, is accurate, and is linear for large strains [2,3]. The capacitance extensometer system had a linearity range in excess of $2.5 \mathrm{~cm}$ ( $1.0 \mathrm{in}$ ) when used with the current foam specimen geometry (5.1 cm diameter by $10.2 \mathrm{~cm}$ long). Similar extensometers can be designed for specific sensitivities and extents of linearity [4]. As long as the capacitance extensometer is situated in a stable fluid (i.e., single phase--no boiling) the result is a low-noise, output signal. These sensors function in gases as well as in liquids. The original calibration of the system, for example, could have been performed at room temperature in air. To conduct a test in any other media (e.g., liquid nitrogen) the original calibration need only be corrected for the change in dielectric constant [5].

\section{ILATERIAL CHARACTERIZATION}

The material tested in this study is a nominal $32 \mathrm{~kg} / \mathrm{m}^{3}$ polyurethane foam (PU) designated as GM30. This amorphous, organic polymer is a thermosetting foam. Our supply of this material was obtained from the NBS Office of Standard Reference Materials (OSRM), Washington, D.C. The OSRI distributed this and other expanded plastics for the Products Research Comittee [6]. These materials were commercially produced and designated as General Materials.

†This work was supported by the Gas Research Institute, 8600 West Bryn Ilawr Avenue, Chicago, Illinois 60631 . 
Our bulk supply of GM30 was in the form of a $0.1 \times 0.2 \times 1.8 \mathrm{~m}$ slab. The physical tests were conducted on specimens taken from the area indicated in figure 1 . The orientation of the elongated cell axis for the material used in the physical properties tests was determined optically from statistical evaluation or microphotographs. The ratios of cell height to cell width for the principal orthogonal planes of the physical test specimens were: $\mathrm{x} / \mathrm{y}=1.33 \pm 0.24, \mathrm{z} / \mathrm{x}=1.02 \pm 0.18, \mathrm{z} / \mathrm{y}=1.40 \pm 0.26$. The uncertainties given represent estimates of one standard deviation. The cell orientation relative to the orthogonal axes of the bulk slab are shown in figure 2 .

The chemical formula of the polyurethane resin is $\mathrm{C}_{10 \cdot 47} \mathrm{H}_{11} \cdot 99 \mathrm{O}_{2} \cdot 38 \mathrm{~N}$. The cellular gas content, although of secondary importance to the properties being reported here, was found by mass spectrography to be (in mole percent): $\mathrm{CCl}_{3} \mathrm{~F}, 71.2 \% ; \mathrm{N}_{2}, 6.1 \% ; 02,21.8 \%$; $\mathrm{A}, \mathrm{CO}_{2}$, $\mathrm{CO}$ and $\mathrm{F}, 1 \%$. The cellular gas pressure was approximately $66 \mathrm{kPa}(0.65 \mathrm{~atm})$. The apparent density of the resin-gas composite was found to be $32.4 \pm 0.5 \mathrm{~kg} / \mathrm{m}^{3}$ at ambient temperature and humidity. Conditioning at $23^{\circ} \mathrm{C}$ and $50 \%$ relative humidity caused an estimated $2.7 \%$ volume increase and a resulting density of $31.7 \mathrm{~kg} / \mathrm{m}^{3}$.

\section{SPECIMENS}

The tensile specimens were rods $9.9 \mathrm{~cm}$ long and $2.9 \mathrm{~cm}$ in diameter. For the determination of ultimate strength, a reduced section specimen was used. The gage length was approximately $5.1 \mathrm{~cm}$ and $1.9 \mathrm{~cm}$ in diameter. All tensile specimens were epoxied to threaded polycarbonate grips. The reduced section geometry forced fracture to occur within the gage length, thereby eliminating premature failure at the grip ends due to biaxial stresses. All other mechanical properties, such as Young's modulus, proportional limit, and yield stress, were derived using the rod geometry.

The compression specimens were $2.54 \mathrm{~cm}$ long and $2.9 \mathrm{~cm}$ in diameter.

Shear specimens were approximately $1.9 \mathrm{~cm} \times 2.54 \mathrm{~cm} \times 0.4 \mathrm{~cm}$. These specimens were epoxied to flat plates and each plate was attached to a pull-rod. An aluminum cylinder was slipped over the specimen and plates to help maintain alignment during testing and to minimize induced torque.

\section{RESULTS}

The results are presented in tables 1 through 3 and in figures 1 through 7 . The error bars on the figures show the data spread from repeated tests. Scatter is typically higher for compression and shear tests than for tensile tests, since the former tests are more sensitive to misalignment. Two orientations, longitudinal and transverse, are designated in the data. These orientations are relative to the axes of the bulk supply, not the true cell orientation.

As shown in the figures, Young's modulus, proportional limit, yield strength, ultimate strength, and shear strength increase as temperature is lowered from 295 to $76 \mathrm{~K}$. The longitudinal specimens are, in general, stronger and stiffer than those tested in the transverse direction (figs. 1, 2, and 4). An exception to this is seen in the compressive yield strength (fig. 5) where the longitudinal and transverse curves cross between 76 and $111 \mathrm{~K}$. Tensile strain decreases with temperature (fig. 3); the material is completely brittle for temperatures below $111 \mathrm{~K}$. Figure 6 indicates a significant deformation capability in compression at low temperatures. The apparent plastic strain is probably caused by a collapse of the cell structure. The polyurethane resin is actually brittle at cryogenic temperatures and cannot exhibit true plastic deformation.

\section{DISCUSSION}

In many respects the polyurethane foam behavior is typical of polymers in general. Expected behavior for a temperature reduction from $295 \mathrm{~K}$ to $76 \mathrm{~K}$ includes large mechanical property changes such as complete loss of ductility and doubling of Young's modulus in tension. Longitudinal shear strength and longitudinal Young's modulus in compression exhibit a maximum between 76 and $295 \mathrm{~K}$. The cause of this behavior is not known at the present time. 
Sectioning after testing revealed that cell orientation varied somewhat from the orientation of the mold axes. It is generally thought that foam specimens from the center of a large billet have uniform cells oriented with respect to the vertical. But this is not true in the case of foams formed on a continuous or bun-line production facility. The cell orientation reflects the movement of the foaming resin. Cells in the $x-z$ plane of the material reported here have nearly a $45^{\circ}$ inclination to the $x$-axis (fig. 2), whereas in the $y-z$ plane there is no inclination from the z-axis. Future tests will include measurement of physical properties perpendicular and parallel to the cell axes, rather than the mold axes as reported in this study.

Specimens tested in liquid nitrogen appeared to have slightly lower shear strength values than those tested at the same temperature in cold helium gas. This may be an indication of environmental sensitivity. Nitrogen at low temperatures is deleterious to a number of other polymeric materials. Thermoplastics have exhibited crazing or reduced fracture strengths, or both when tensile tested in cold liquid or gaseous nitrogen, as compared with vacuum or helium environments [8]. Environmental effects must ultimately be taken into account in design applications.

\section{BIBLIOGRAPHY}

[1] R. P. Reed, J. M. Arvidson, and R. L. Durcholz, Tensile properties of polyurethane and polystyrene foams from 76 to $300 \mathrm{~K}$, in: "Advances in Cryogenic Engineering," Vol. 18, K. D. Timmerhaus, ed., Plenum Press, New York (1973), pp. 184-193.

[2] J. M. Roberts, R. B. Herring, and D. E. Hartman, The use of capacitance gauge sensors to make precision mechanical property measurements, in: "Materials Technology," American Society for Mechanical Engineers, New York (1968), pp. 87-96.

[3] "High-Temperature Capacitive Strain Measurement System," NASA Tech. Brief B75-10069, NASA (1975).

[4] P. C. F. Woldendale, Capacitive displacement transducers with high accuracy and resolution, J. Sci. Instrum. (J. Phys. E.) $1: 817$ (1968).

[5] G. R. White, Measurement of thermal expansion at low temperatures, Cryogenics, $2: 151$ (1961).

[6] "Materials Bank Compendium of Fire Property Data," Products Research Committee, J. W. Lyons, chairman, National Bureau of Standards, Washington, D.C. (1980).

[7] W. G. Jurevic, "Structural Plastics Applications Handbook, Supplement 1 Test Methods," Technical Report AFML-TR-67-332 (1969).

[8] A. Hiltner and E. Baer, Mechanical properties of polymers at cryogenic temperatures, Polymer 15:805 (1974). 
Table 1. Summary of tensile test results for a $32 \mathrm{~kg} / \mathrm{m}^{3}$ polyurethane foam (average values).

\begin{tabular}{|c|c|c|c|c|c|}
\hline $\begin{array}{l}\text { Material } \\
\text { Property }\end{array}$ & $\begin{array}{c}\text { Specimen } \\
\text { Orientation* }\end{array}$ & $295 \mathrm{~K}$ & $111 \mathrm{~K}$ & $76 \mathrm{~K}$ & $45 \mathrm{~K}$ \\
\hline $\begin{array}{l}\text { Young's } \\
\text { Modulus } \\
\text { MPa (psi) }\end{array}$ & $\begin{array}{l}\mathrm{L} \\
\mathrm{T}\end{array}$ & $\begin{aligned} 13.61 & (1,980) \\
7.26 & (1,050)\end{aligned}$ & $\begin{array}{ll}24.41 & (3,540) \\
12.81 & (1,860)\end{array}$ & $\begin{array}{ll}26.37 & (3,820) \\
14.27 & (2,070)\end{array}$ & $\begin{array}{c}26.95 \\
-\end{array}$ \\
\hline $\begin{array}{l}\text { Proportional } \\
\text { Limit, } \\
\text { MPa (psi) }\end{array}$ & $\begin{array}{l}\mathrm{L} \\
\mathrm{T}\end{array}$ & $\begin{array}{ll}0.166 & (23.91) \\
0.077 & (11.17)\end{array}$ & - & - & - \\
\hline $\begin{array}{l}\text { Yield Strength } \\
(0.2 \% \text { Offset), } \\
\mathrm{MPa} \text { (psi) }\end{array}$ & $\begin{array}{l}\mathrm{L} \\
\mathrm{T}\end{array}$ & $\begin{array}{l}0.265(38.46) \\
0.130(18.93)\end{array}$ & - & - & - \\
\hline $\begin{array}{l}\text { U1timate Ten- } \\
\text { sile Strength, } \\
\text { Mpa (psi) }\end{array}$ & $\begin{array}{l}\mathrm{L} \\
\mathrm{T}\end{array}$ & $\begin{array}{ll}0.458 & (66.43) \\
0.365 & (52.85)\end{array}$ & $\begin{array}{ll}0.491 & (71.23) \\
0.368 & (53.43)\end{array}$ & $\begin{array}{l}0.490(71.08) \\
0.386(55.93)\end{array}$ & - \\
\hline $\begin{array}{c}\text { Elongation \% } \\
\text { Elastic } \\
\text { Plastic } \\
\text { Total }\end{array}$ & $\mathrm{L}$ & $\begin{array}{l}3.1 \\
2.5 \\
5.6\end{array}$ & $\begin{array}{r}2.0 \\
0 \\
2.0\end{array}$ & $\begin{array}{r}2.0 \\
0 \\
2.0\end{array}$ & $\begin{array}{l}- \\
- \\
-\end{array}$ \\
\hline $\begin{array}{r}\text { Elastic } \\
\text { Plastic } \\
\text { Total }\end{array}$ & $\mathrm{T}$ & $\begin{array}{r}5.0 \\
10.6 \\
15.6\end{array}$ & $\begin{array}{r}2.9 \\
0 \\
2.9\end{array}$ & $\begin{array}{r}2.7 \\
0 \\
2.7\end{array}$ & $\begin{array}{l}- \\
- \\
-\end{array}$ \\
\hline
\end{tabular}

*L: longitudinal; $\mathrm{T}$ : transverse 
Table 2. Summary of compression test results for a $32 \mathrm{~kg} / \mathrm{m}^{3}$ polyurethane foam (average values).

\begin{tabular}{|c|c|c|c|c|}
\hline $\begin{array}{l}\text { Material } \\
\text { Property }\end{array}$ & $\begin{array}{c}\text { Specimen } \\
\text { Orientation }\end{array}$ & $295 \mathrm{~K}$ & $111 \mathrm{~K}$ & $76 \mathrm{~K}$ \\
\hline $\begin{array}{l}\text { Young's } \\
\text { Modulus } \\
\mathrm{MPa} \text { (psi) }\end{array}$ & $\begin{array}{l}\mathrm{L} \\
\mathrm{T}\end{array}$ & $\begin{array}{l}8.48(1,230) \\
6.03\left(\begin{array}{r}(880)\end{array}\right.\end{array}$ & $\begin{array}{rr}14.88 & (2,160) \\
6.69 & (970)\end{array}$ & $\begin{array}{r}13.26(1,920) \\
6.40(930)\end{array}$ \\
\hline $\begin{array}{l}\text { Proportional } \\
\text { Limit, } \\
\mathrm{MPa} \text { (psi) }\end{array}$ & $\begin{array}{l}\mathrm{L} \\
\mathrm{T}\end{array}$ & $\begin{array}{l}0.067(9.70) \\
0.073(10.63)\end{array}$ & $\begin{array}{ll}0.079 & (11.47) \\
0.150 & (21.75)\end{array}$ & $\begin{array}{ll}0.152 & (22.03) \\
0.118 & (17.14)\end{array}$ \\
\hline $\begin{array}{l}\text { Yield St rength } \\
(0.2 \% \text { Offset), } \\
\mathrm{MPa} \text { (psi) }\end{array}$ & $\begin{array}{l}\mathrm{L} \\
\mathrm{T}\end{array}$ & $\begin{array}{ll}0.114 & (16.57) \\
0.109 & (15.80)\end{array}$ & $\begin{array}{ll}0.146 & (21.15) \\
0.179 & (26.04)\end{array}$ & $\begin{array}{ll}0.204 & (29.60) \\
0.172 & (24.98)\end{array}$ \\
\hline $\begin{array}{l}\text { Maximum Compres- } \\
\text { sive Strength, } \\
\text { Mpa (psi) }\end{array}$ & $\begin{array}{l}\mathrm{L} \\
\mathrm{T}\end{array}$ & $\begin{array}{ll}0.287 & (41.62) \\
0.218 & (31.60)\end{array}$ & $\begin{array}{ll}0.311 & (45.12) \\
0.247 & (35.91)\end{array}$ & $\begin{array}{ll}0.338 & (49.02) \\
0.227 & (32.93)\end{array}$ \\
\hline $\begin{array}{c}\text { Elongation \% } \\
\text { Elastic } \\
\text { Plastic } \\
\text { Tota1 }\end{array}$ & L & $\begin{array}{l}3.3 \\
4.4 \\
7.7\end{array}$ & $\begin{array}{r}1.9 \\
12.4 \\
14.3\end{array}$ & $\begin{array}{r}2.5 \\
9.4 \\
11.9\end{array}$ \\
\hline $\begin{array}{r}\text { Elastic } \\
\text { Plastic } \\
\text { Total }\end{array}$ & $\mathrm{T}$ & $\begin{array}{l}3.0 \\
5.4 \\
8.4\end{array}$ & $\begin{array}{r}3.4 \\
10.5 \\
13.9\end{array}$ & $\begin{array}{r}3.3 \\
15.2 \\
18.5\end{array}$ \\
\hline
\end{tabular}

Table 3. Summary of shear test results for a $32 \mathrm{~kg} / \mathrm{m}^{3}$ polyurethane foam (average values).

\begin{tabular}{cccc}
\hline \multirow{2}{*}{ Test Temperature, $\mathrm{K}$} & Specimen & \multicolumn{2}{c}{ Shear Strength } \\
\cline { 3 - 4 } 295 & $\mathrm{~L}$ & 0.217 & psi \\
\hline \multirow{2}{*}{111} & $\mathrm{~T}$ & 0.217 & 31.47 \\
& & & 31.43 \\
76 & $\mathrm{~L}$ & 0.266 & 38.62 \\
& $\mathrm{~T}$ & 0.219 & 31.74 \\
& $\mathrm{~L}$ & 0.242 & 35.14 \\
$76 *$ & $\mathrm{~T}$ & 0.225 & 32.65 \\
& & & 34.95 \\
& $\mathrm{~L}$ & 0.241 & 31.39 \\
\hline
\end{tabular}

*Test conducted in $\mathrm{LN}_{2}$ 


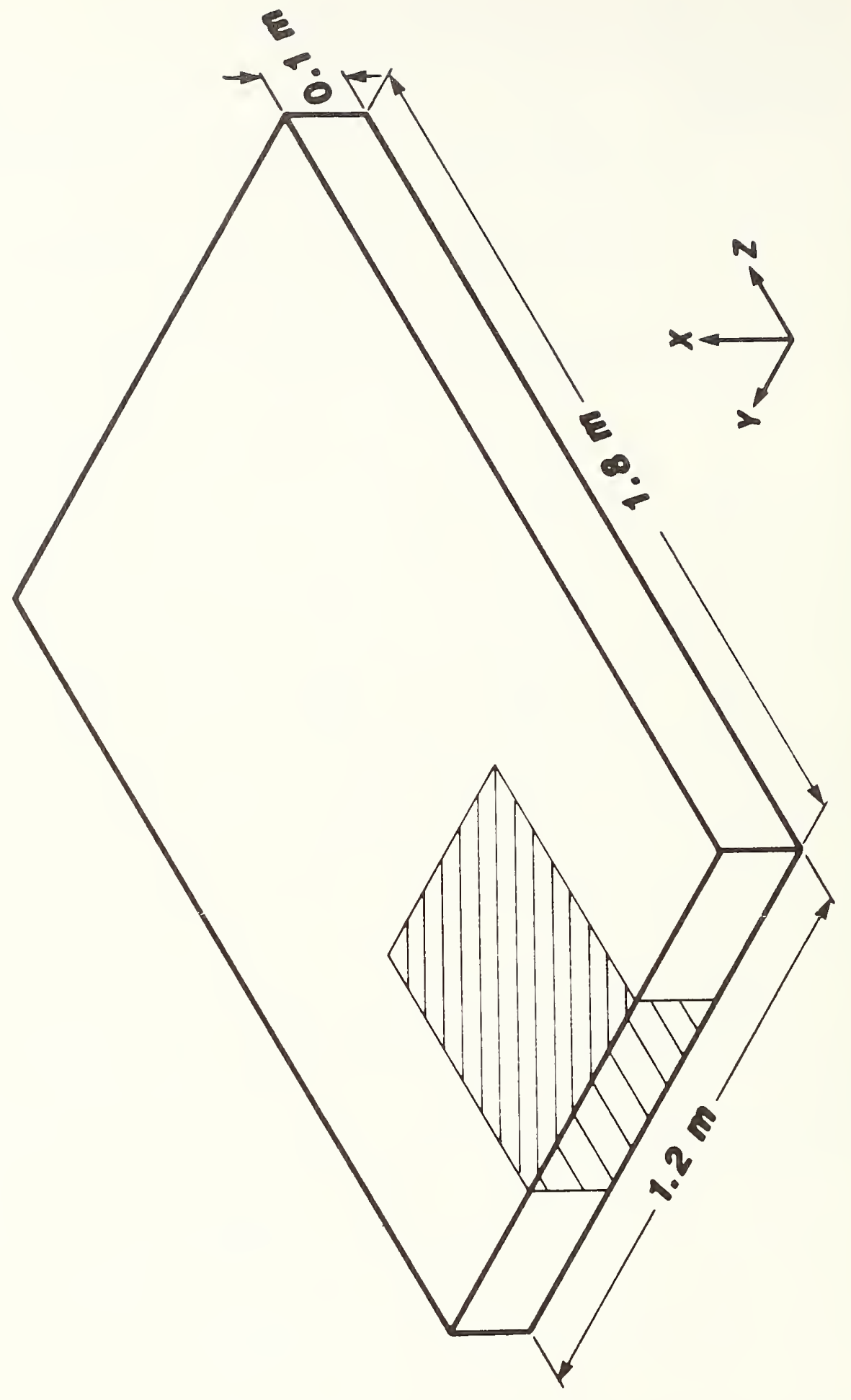

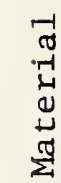

峁

ชే

ह

ำ

苗

壳

극 주

¿워

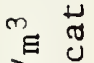

我

N

ल)

वृ

ปี

논

() ब

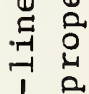

12

วิ

点

出造

금

के त्ञ

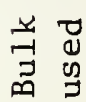

$-i$

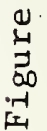



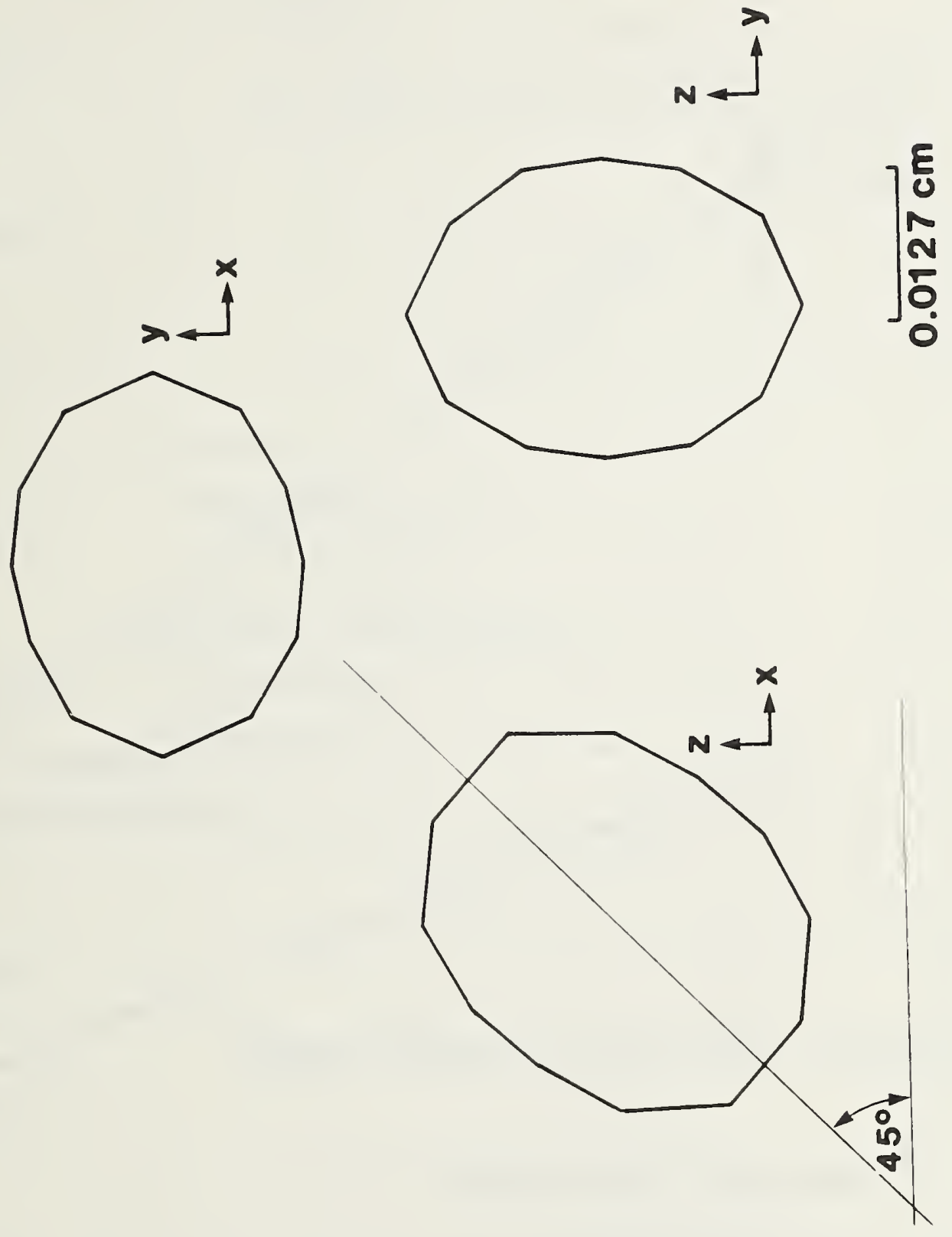

노ㅇㅝㅗㅇ

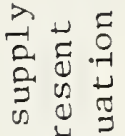

분

马े

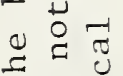

+ 엄

出

$0 \stackrel{\vec{\sigma}}{\sim}$

(1)

$\pi$ o

I is

.

$\tau$

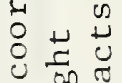

4.7

品焉

茞 的 $\pi \cdot-$

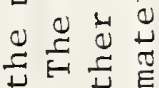

मैE

$\stackrel{\circ}{\sim} \stackrel{0}{0}$

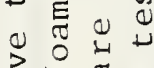

.

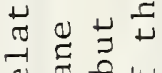

일

㟧 0

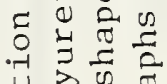

$\sim \frac{\pi}{0}-\frac{\pi}{0}$

대어

-rm u 0

- $\frac{E}{2}-\frac{1}{2}$

$\neg$.

Uू

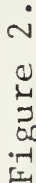




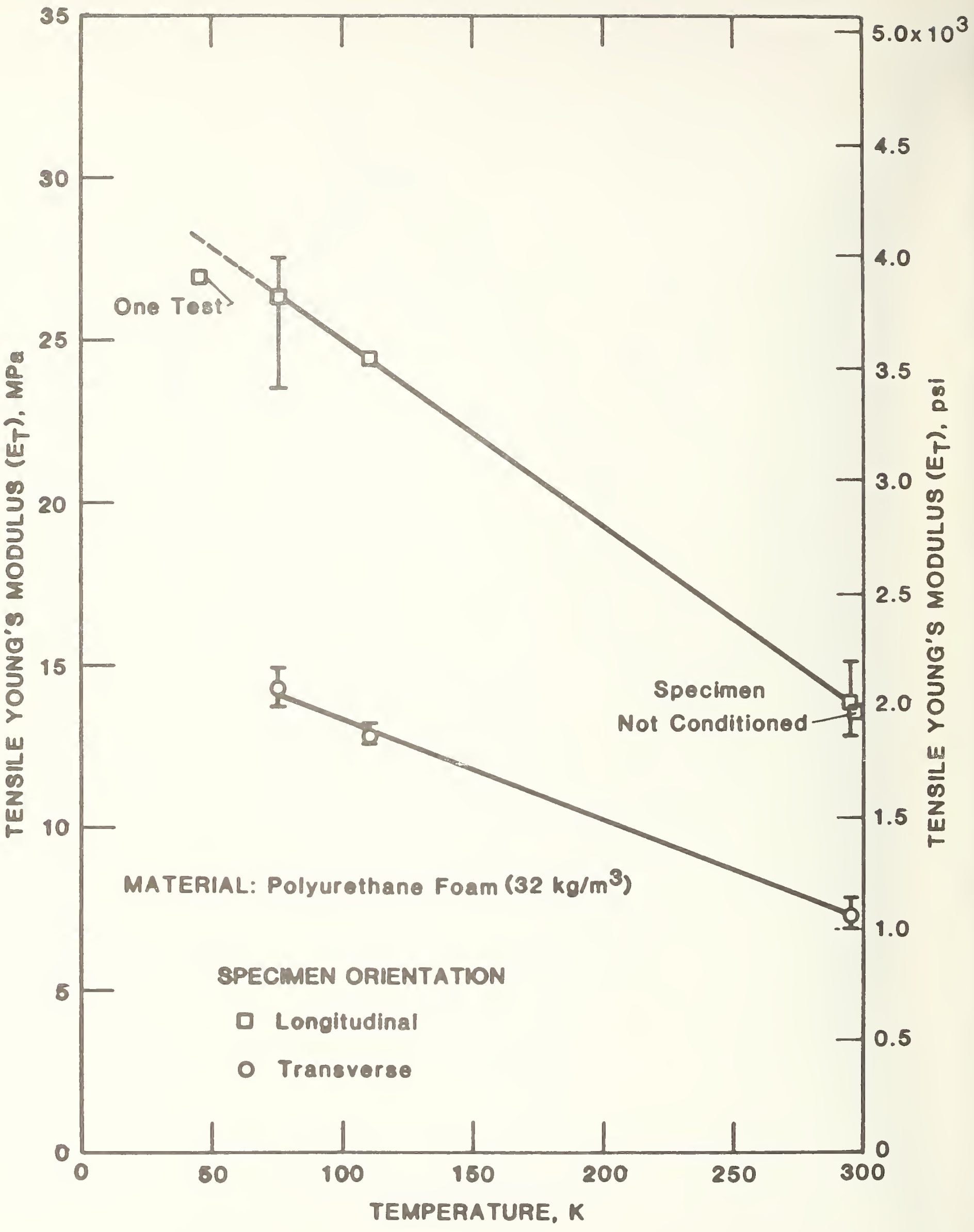

Figure 3. Tensile Young's modulus versus temperature. 


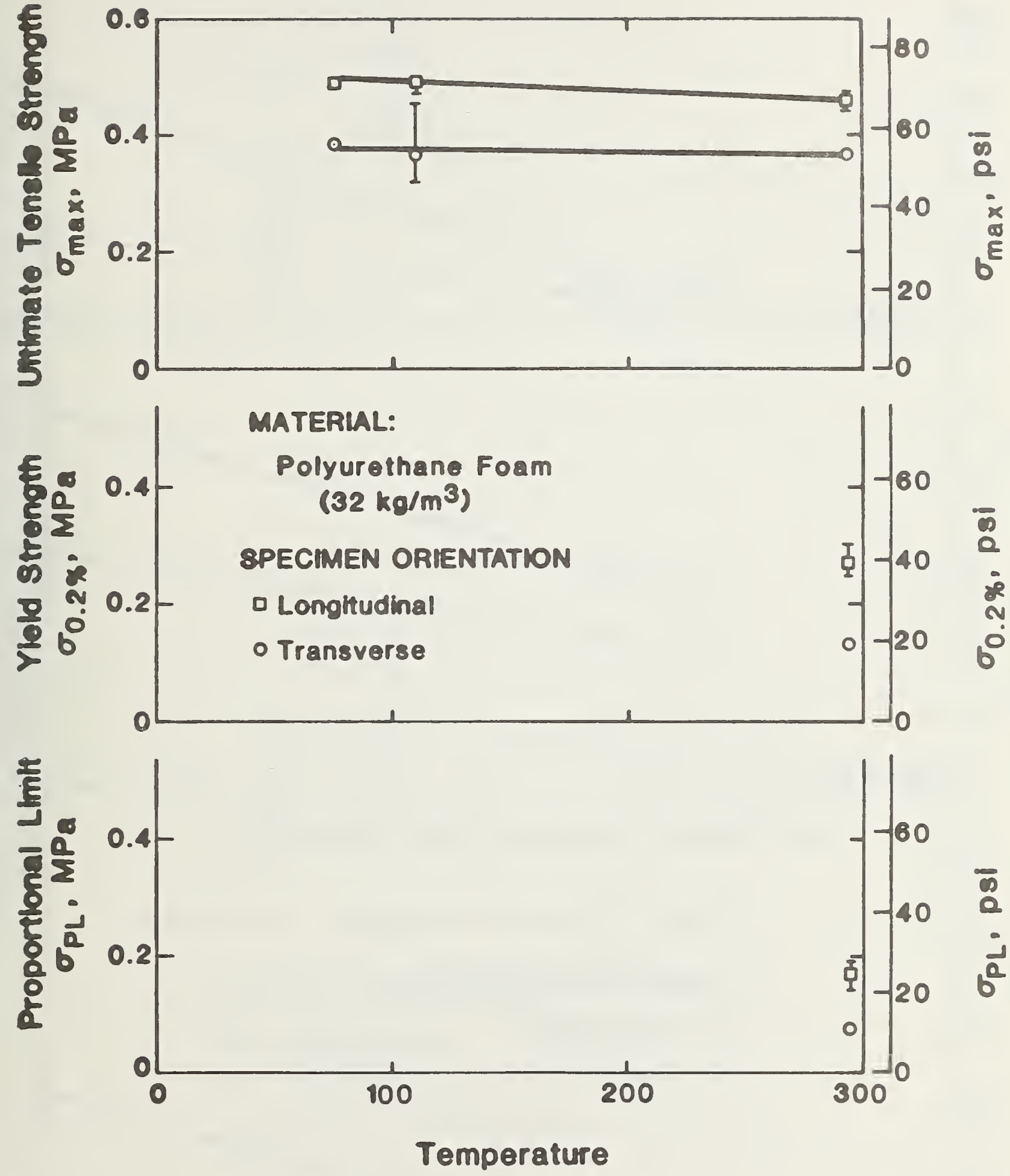

Figure 4. Tensile test results: proportional limit, yield strength, and ultimate strength versus temperature. 


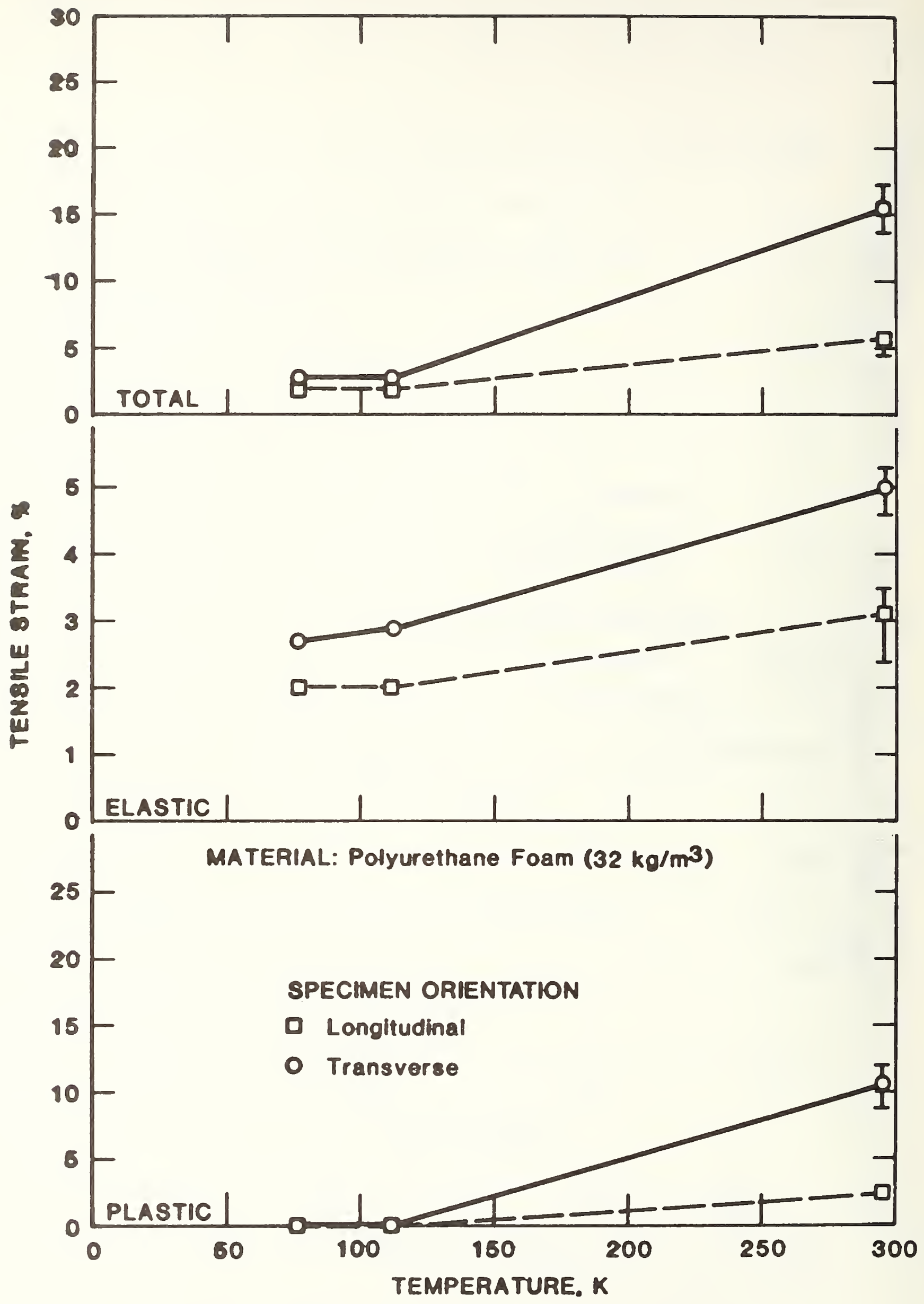

Figure 5. Tensile strain versus temperature. 


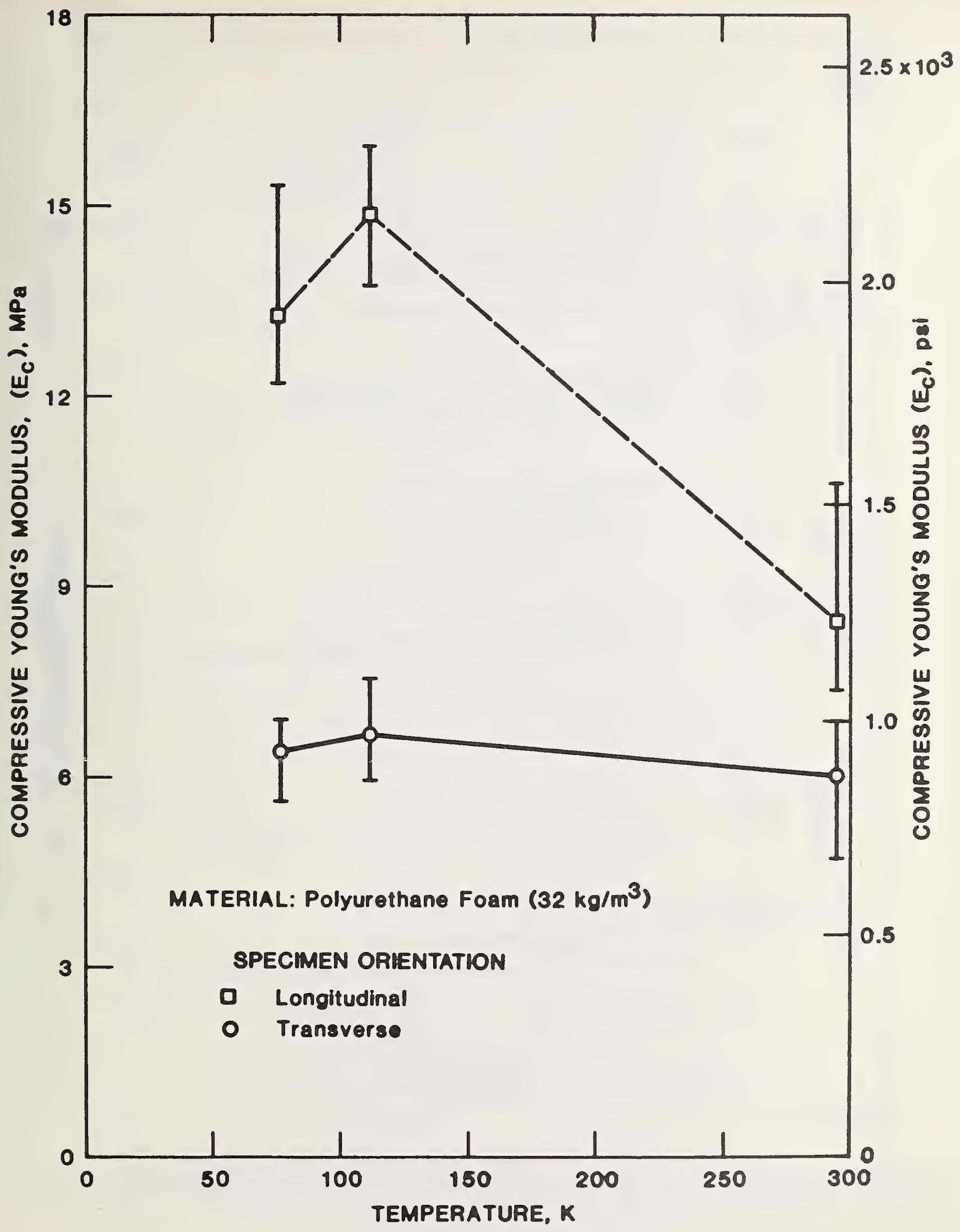

Figure 6. Compressive Young's modulus versus temperature. 


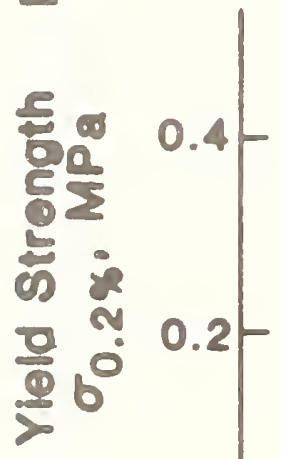

MATERIAL:

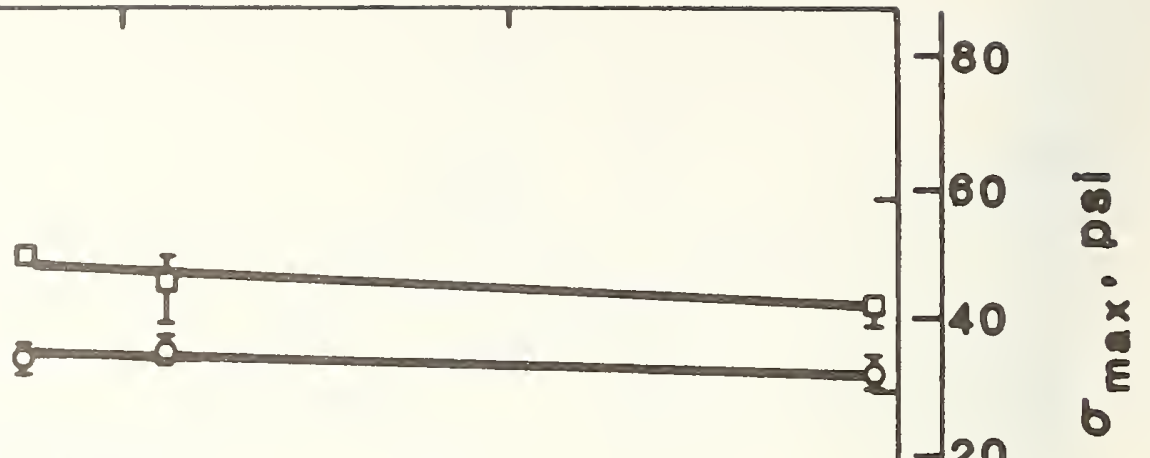

Polyurethane Foam $\left(32 \mathrm{~kg} / \mathrm{m}^{3}\right)$

\section{SPECMEN ORIENTATION}

- Longltudinal

- Transverse
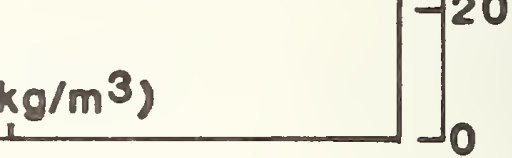

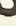
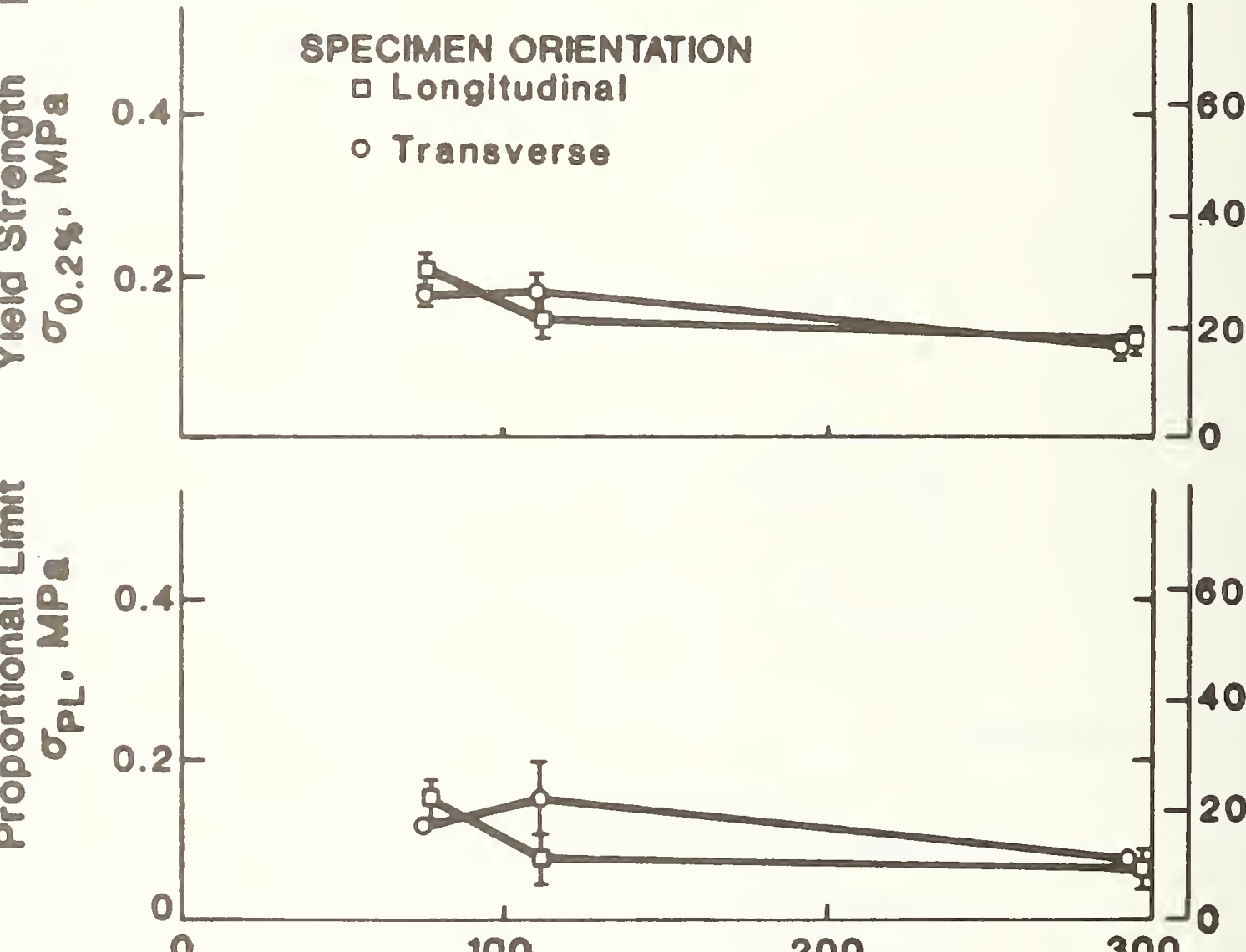

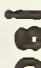

Q

i

\section{है}

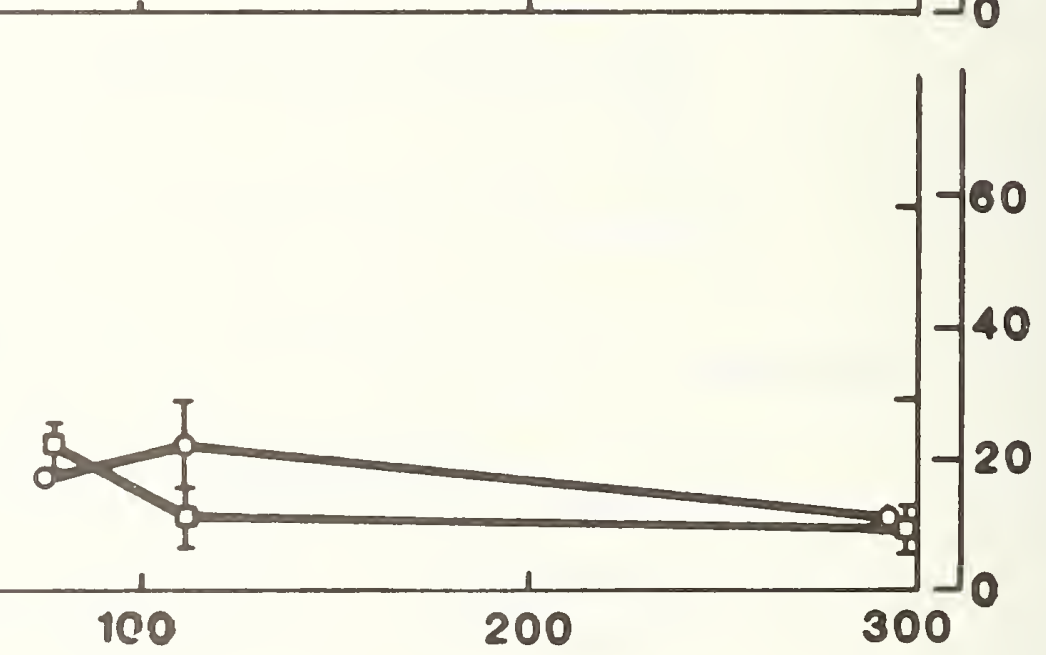

0
0
0

Temperature

Figure 7. Compression test results: proportional limit, yield strength, and maximum compressive strength versus temperature. 


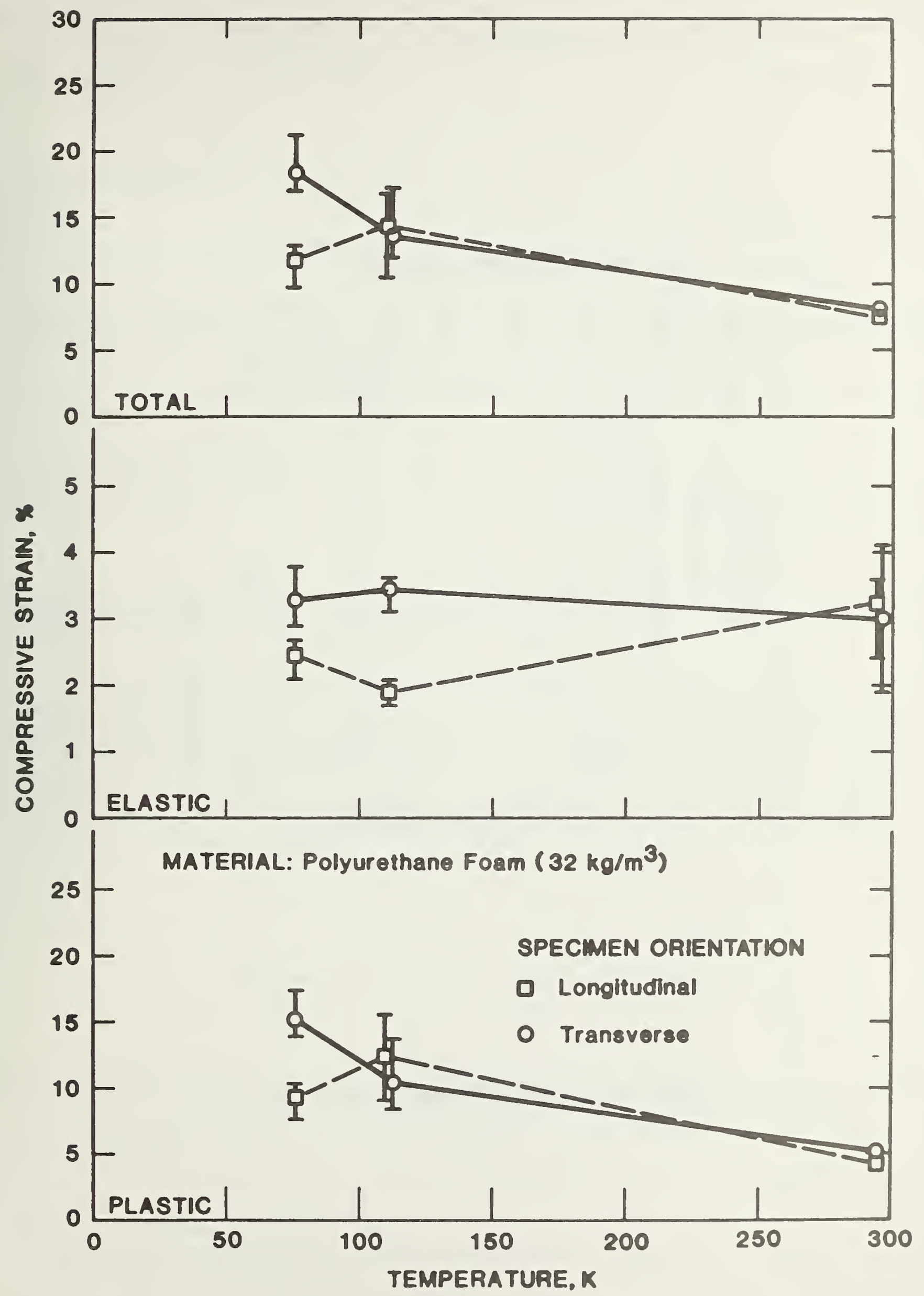

Figure 8. Compressive strain versus temperature. 


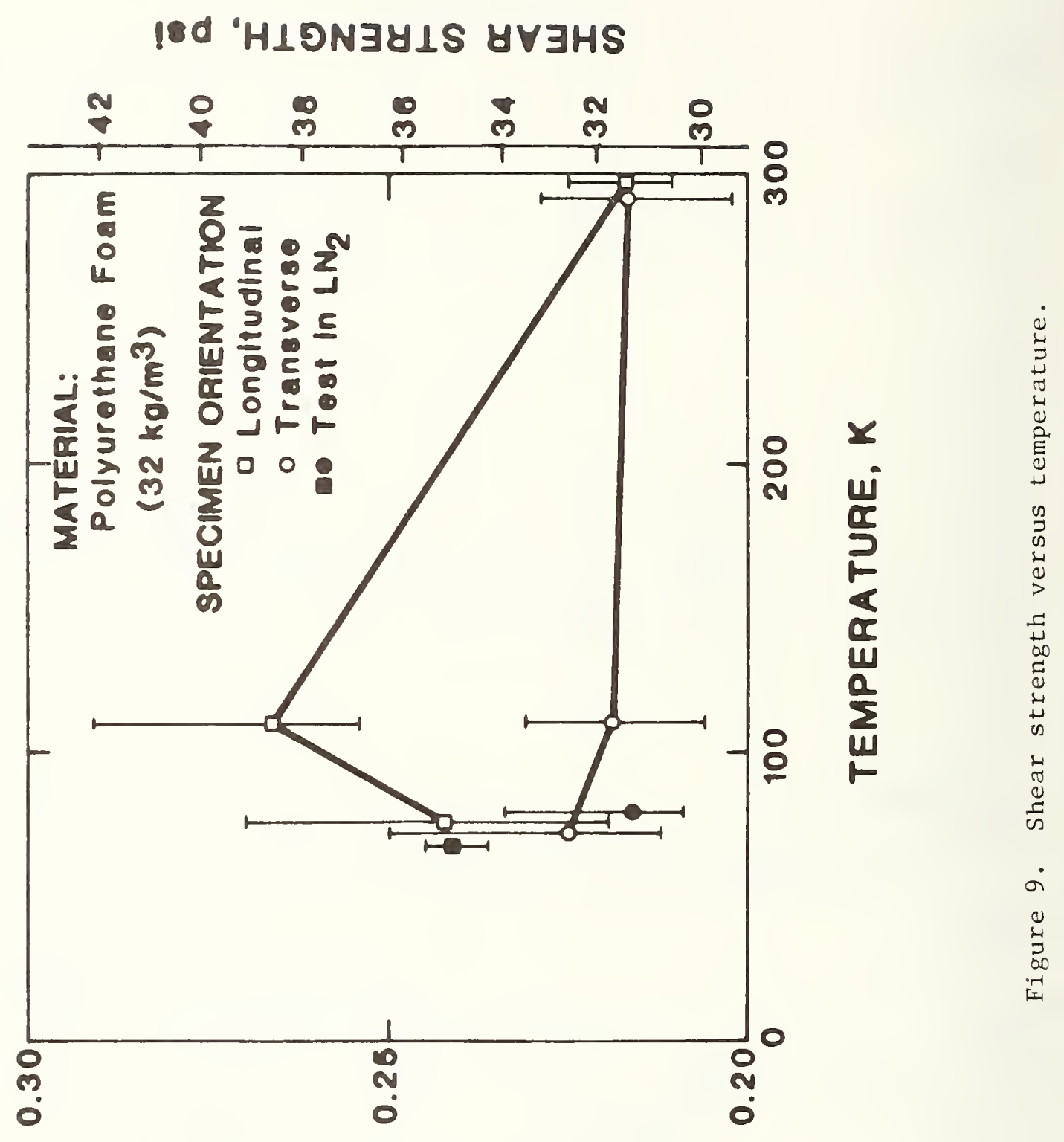

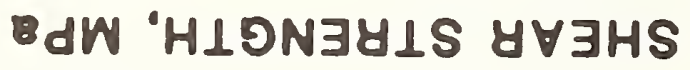


NES-114A (REV. 2.8C)

U.S. DEPT. OF COMM.

1. PUBLICATION OR

2. Performing Organ. Report No REPORT NO.

BIBLIOGRAPHIC DATA NBSIR $81-1654$

November 1981

SHEET (See instruction s)

4. TITLE AND SUBTITLE

Low Temperature Mechanical Properties of a

Polyurethane Foam

5. $\operatorname{AUTHOR}(S)$

J. M. Arvidson and L. L. Sparks

6. PERFORMING ORGANIZATION (If joint or other than NBS, see instructions)

7. Contract/Grant No.

NATIONAL BUREAU OF STANDARDS

DEPARTMENT OF COMMERCE

WASHINGTON, D.C. 20234

8. Type of Report \& Period Covered

9. SPONSORING ORGANIZATION NAME AND COMPLETE ADDRESS (Street, City, State, ZIP)

Gas Research Institute

8600 West Bryn Mawr Avenue

Chicago, Illinois 60631

10. SUPPLEMENTARY NOTES

[Document describes a computer program; SF-185, FIPS Software Summary, is attached.

11. ABSTRACT (A 200-word or less factual summary of most significant information. If document includes a significant bibliography or literature survey. mention it here)

Polyurethare foam, having a density of $32 \mathrm{~kg} / \mathrm{m}^{3}$, was tested at $295,111,76$, and $45 \mathrm{~K}$ in helium gas. The material properties reported are Young's modulus, proportional limit, yield strength (at $0.2 \%$ offset), tensile, shear, and compressive strengths, and elongation (elastic and plastic). To perform these tests, a unique apparatus was developed. This apparatus permits tension, compression, and shear testing of materials at any temperature ranging from 295 to $4 \mathrm{~K}$. Strain is measured with a concentric, overlapping-cylinder capacitance extensometer that is highly sensitive and linear in output.

12. KEY WORDS (Six to twelve entries; alphabetical order; capitalize only proper names; and separate key words by semicolons) compressive strength; elongation; foam; insulation; low temperature; mechanical properties; proportional limit; shear strength; tensile strength; yield strength; Young's modulus.

13. AVAILABILITY

X] Unlimited

$\square$ For Official Distribution. Do Not Release to NTIS

$\square$ Order From Superintendent of Documents, U.S. Government Printing Office, Washington, D.C. 20402.

X] Order From National Technical Information Service (NTIS), Springfield, VA. 22I6I

14. NO. OF PRINTED PAGES

17

15. Price

$\$ 5.00$ 




